\title{
SOCIALIZATION OF THE IMPACT OF VIOLENCE THROUGH MASS MEDIA ON AGGRESSIVE BEHAVIOR
}

\author{
Inge HUTAGALUNG \\ Universitas Mercu Buana, Indonesia \\ inge_hutagalung@yahoo.com; inge_hutagalung@mercubuana.ac.id
}

\begin{abstract}
Society in the current era of reformation has actually been presented with the naked staging of what the French poststructuralist thinker Jean Baudrillard (1983) calls a 'theater of cruelty'. As theater, violence, cruelty and ruthlessness have become a kind of ritual that is staged into the public sphere. Violence has become a discourse in the public sphere. The social learning theory proposition states that humans imitate and identify by learning through observing the behavior of others around them, including through mass media. The purpose of community service activities $(\mathrm{PkM})$ is to socialize the impact of violent broadcasts on aggressive behavior, given the role of the mass media as a double-edged knife, having both a function and a dysfunction. The function of the media to inform reality can ultimately have negative side effects. The method of implementation is done through Learning Methodology, a method that focuses on participant participation. The result of this PkM activity is an increase in public awareness of the impact of the mass media. Because if society is constantly being fed with the values of violence, over time there will be an assumption that violence is commonplace, and will make the community insensitive to violence. As a result, in a broad sense, there will be chaos in the social values and norms of society, where the good and true values are confused.
\end{abstract}

Keywords : Violence, aggressive behavior, good and right values

\section{BACKGROUND}

Since the Indonesian political system enacted Law No. 40 of 1999, normatively, the Indonesian media has embraced the theory of the social responsibility press, namely freedom of the press that is accountable to the public / public interest. However, in practice until now press freedom has not taken place substantially, the increase in the quantity of media has not been accompanied by an improvement in the quality of journalism. There are so many violations of ethics and professionalism. Public criticism, especially on criminal news and pornography, is often directed at media managers. Based on the results of a survey conducted by the Ministry of Communication and Information Technology of the Republic of Indonesia (2014), it is known that (80\%) children and adolescents in Indonesia are internet users, and 97\% of Indonesian teenagers access porn sites and watch pornographic films via the internet (Hutagalung, 2018; Kholisoh, 2018).

The position of children on what is presented by the mass media is very weak. This is related to the nature of children, namely first, children find it difficult to distinguish good or bad information or impressions, which ones deserve to be imitated or ignored. Second, children do not have self-censorship and do not have value limits. Third, children who get information and impressions through the mass media tend to be passive and uncritical. As a result, all information and impressions obtained from the mass media will be considered normal. These characteristics are particularly vulnerable if the information or impressions received through the mass media have an 'anti-social' smell, such as violence and pornography. Moreover, the quality of the shows that are broadcast on television is generally not in favor of children. As an example of the Smack Down case, it appears that children imitate free fighting demonstrations like the shadow boxing of the fighters. Namely punching each other, kicking each other, elbowing each other, even slamming each other, this is because they often see Smack Down shows on television. They do not understand if the show that looks exciting is actually a fight scene that has been arranged according to the scenario to look like a death fight scene, which is engineered using mere television camera tricks. This broadcast has also claimed the life of a child who died after being treated by friends as a victim like Smack Down wrestling on television. Children with fracture injuries and material losses who have a lot of money for treatment are the results of the Smack Down impressions.

Another example is the story of a cartoon character named Sinchan, who often behaves "indecently" towards teachers at school. Sinchan is not a good role model for children. But strangely, this Sinchan film got a place and is very popular with almost all children in this country.

Research by Mahsiani (2018), Satriyandari (2017), and Siregar (2014), reinforces that mass media is one of the factors that influence the occurrence of violence. Mass media such as television provides the largest contribution regarding violent broadcasts. Television also influences youth behavior to commit physical violence, mental violence, and even sexual violence. Regarding the publication of pornography, research by Anisah (2016), Hutagalung (2017), and Mahsiani (2018) explained that teenagers often seek pornographic information because they have difficulty finding sources of information on sexuality. To ask parents about sexuality is very unlikely because it is considered taboo, asking the teacher is shame. As a result, adolescents seek sexuality information on pornographic information through mass media, especially on social media.

Furthermore, Matar \& Jaalouk (2017) and Mariyati (2018) emphasize that pornographic publications through film, internet and print media can influence adolescent attitudes and behavior. Pornography can have a negative 
impact on the growth of the brains of those who access it. Pornography has a very detrimental impact because it can damage five parts of the brain, especially the prefrontal cortex which is located near the frontal bone, continuous excessive stimulation without filters from pornography can permanently damage the logical part of the brain. This can cause several symptoms such as boredom, feelings of isolation, anger, feeling depressed, and tiredness. In addition, another effect related to pornography is how it can negatively impact students' academic performance, study skills, and decision-making skills.

One of the communication theories that studies the impact of mass media, specifically analyzing the possible impact of violence broadcasted by mass media is social learning theory, which is a theory from the field of psychology in a behavioristic perspective. Social learning theory recognizes that humans have the ability to realize or think about the benefits that can be drawn from observation and experience. The proposition built by social learning theory is that humans imitate and identify by learning through observation of the behavior of others around them, including through mass media.

Recognizing that if the broadcast of violence through mass media is not handled professionally it will open up opportunities for the mass media to become the biggest contributor to the dissemination of negative social values, it is necessary to do socialization of the impact of violent broadcasts through mass media on aggressive behavior. It is hoped that through this socialization activity, mass media can be considered as a tool of social integration and not social disintegration, namely the cause of social diseases / problems faced by society such as an increase in criminal problems, violence, sexual deviation (homosexual, pedophilia, prostitution), growth. individualistic attitude, the formation of a virtual society, and others.

\section{TARGET}

In the SmackDown case, the kids clearly imitated their idol character's throwing innocently. In the case of the Sinchan cartoon, children imitate the behavior of the Sinchan character who harasses teachers at school. In both cases, it can be seen that because they like the characters of each show, the actors, consisting of children, pay attention to the shows of their respective characters.

What the actors do is in line with the proposition of social learning theory, which states that humans imitate and identify by learning through observing the behavior of others around them, including through mass media. In this case people learn behavior by studying a behavior through observation and storing these observations as clues for future behavior.

Realizing that what is broadcast or published by the mass media has an impact on behavior, it is necessary to carry out socialization activities in the form of education and literacy regarding the impact of mass media on aggressive behavior. With this socialization activity, it is hoped that the community, especially the participants of the socialization activities, will realize that the mass media contributes to the formation of culture in society, including constructive and destructive culture. Mass media impressions and publications have two different effects, namely imitation and encouragement. Imitation refers to the attempt to imitate directly on the object being observed. Meanwhile, encouragement is an increase in behavior after watching shows or reading what is published.

The targets of the socialization activities are parents who are represented by mothers and young people. The argument is that mothers are the closest parties to child development. Meanwhile, young people are the successors of the nation's generation who must understand that mass media publications can have a negative impact on the survival of a person's life.

Socialization materials were distributed to participants related to theoretical and practical materials. The socialization material is presented in the form of power points as well as cases of the impact of mass media on aggressive behavior. The material is explained interactively in the form of presentations and group discussions. The cases are discussed and practiced in groups.

\section{METHOD}

Socialization of the impact of violent broadcasts through mass media on aggressive behavior using Learning Methodology. It is a method of socialization that engages participants in the process of increasing understanding and knowledge. In other words, the success or failure of the socialization depends on the active role of the participants. In order for the socialization to be carried out effectively, the process of activities was carried out through the provision of material and group discussions.

To see further about the relationship between the publication of violence in the mass media and its impact on human behavior, social learning theory was chosen as a media impact theory for a theoretical approach (Baran, 2000).

Social learning theory is a theory from the field of psychology in a behavioristic perspective that studies the impact of mass media. This theory considers the media as the main socialization agent besides family, school teachers, and best friends. The figure in this theory is Albert Bandura. This theory states that there is a lot of learning through observing the behavior of others. It is also a general learning theory that can be applied to other areas of mass media impact (Bandura, 1994).

According to social learning theory, humans learn through observation (in this case observation through media). Learning is carried out in two forms, namely (1) imitation is a direct reproduction of the observed behavior, (2) identification is a form of imitation, namely copying the model, arising from the desire to be like an observed model by paying attention to a wider number of characteristics and 
qualities . Imitation is more observable than identification, but identification is a more durable and significant media effect. Social learning theory also looks at how imitation and identification can explain how people learn through observing the behavior of others around them.

On the other hand, social learning theory recognizes that people may avoid learning approaches, and may acquire behavior through modeling from the mass media. In this case, people learn behavior by studying a behavior only through observation and storing these observations as clues for future behavior (Severin \& Tankard, 2008).

\section{RESULT AND DISCUSSION}

The theory of social learning through media runs in three ways, namely (1) observational learning, observation through media presentation, (2) inhibitory effects, seeing the model in law will reduce the desire to perform the behavior shown by the model, and (3) disinhibitory effects, that is, seeing the model get rewarded will increase the desire to perform the behavior the model displays.

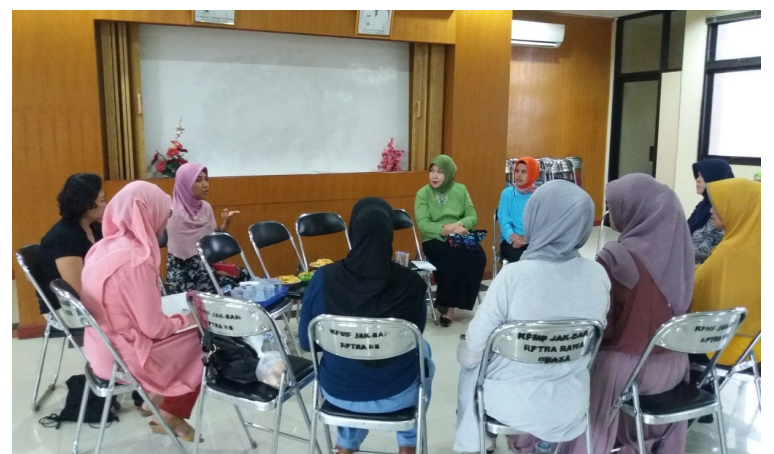

Figure 1. Mapping of problems and level of understanding of impact of impressions mass media, at the Office of the North Meruya Village, West Jakarta.

The objectives of this activity are to: (1) map the problem and the level of understanding on the impact of mass media broadcasts; (2) providing education on the impact of violent broadcasts on mass media on aggressive behavior (3) disseminating preventive measures against violent broadcasts on mass media.

This community service is expected to contribute in the form of data and information related to the impact of mass media violence on people's lives. The information obtained can be taken into consideration for policy making regarding the socialization material that will be provided. The targets of community service are the parents and the young generation. The reason for the election is because parents are the ones who will play a very important role and influence the growth and development of children, while the younger generation (such as: Karang Taruna) is the nation's next generation.

Community service activities related to the socialization of the impact of violent broadcasts on aggressive behavior consist of three stages with details of the stages of the process as follows:

- Stage 1 is a mapping of the problem and the level of understanding of the impact of mass media broadcasts, carried out at the Meruya Utara Village Office, West Jakarta, involving the Head of the PKK Driving Team at the Kelurahan Level and their members.

- Phase 2 is the provision of education on the impact of violence on mass media on aggressive behavior at RPTRA Kelurahan Meruya Utara, West Jakarta, followed by 20 participants from PKK Cadres at Kelurahan Level and Karang Taruna Management in North Meruya Village, West Jakarta.

- Stage 3 is literacy related to preventive measures against the broadcast of violence in the mass media, held at RPTRA Kelurahan Meruya Utara, West Jakarta, followed by 20 participants of PKK Cadres at Kelurahan Level and Karang Taruna Management in Meruya Utara Village, West Jakarta.

\section{CONCLUSION}

From the results of the activity evaluation, it was found that the participants understood the impact of mass media on aggressive behavior. Participants understand the threats and concerns about the impact of the mass media, as well as know the stages of the imitation process on an individual. Furthermore, the participants also understood the steps to deal with the impact of the mass media which can lead to sexual and physical violence.

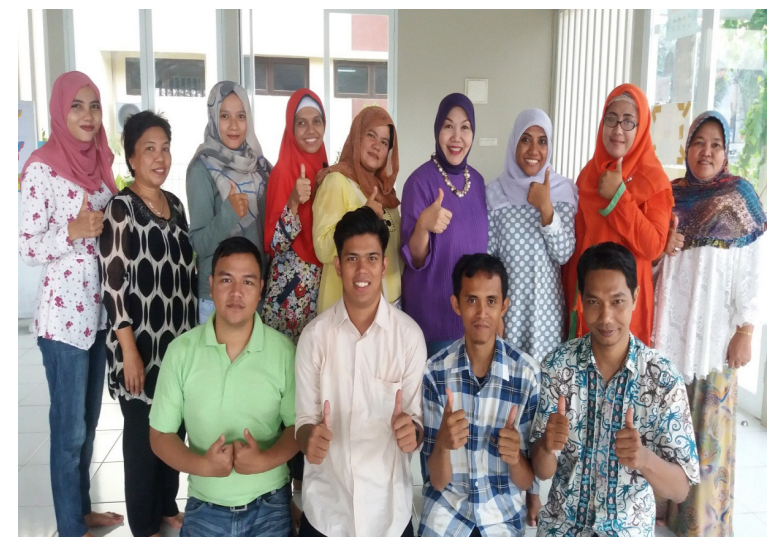

Figure 2. Providing education on the impact of violence on mass media on aggressive behavior at RPTRA Kelurahan Meruya Utara, West Jakarta

Participants' awareness also increased that learning occurs when a behavior is reinforced with an award. Namely, people learn behavior through the stimulus they receive and the response given depends on the reinforcement of the stimulus, whether positive (rewarded) or negative (given punishment). In this way, new behaviors are learned or added to someone's behavior repertoire (individual behavior that already exists in certain situations). In other words, changes in a person's behavior through social learning are always associated with reward and punishment. That is, when a bad character is respected, it will be emulated, on the other hand, if a bad character is punished, the individual will refrain from doing this bad thing. So the behavior is regulated externally by the stimulus conditions caused by the reinforcement condition. 
To increase the socialization program for the impact of mass media on aggressive behavior, the participants hoped that the socialization activities could be carried out in a few more sessions to discuss in detail every impact that mass media had on various conditions. It is also hoped that socialization activities can be carried out on an ongoing basis with various types of participants to develop preventive action and identify the potential for violence as an impact of the mass media without giving fear and limiting the space for the community to use mass media. Finally, it is hoped that parents must always accompany their children when consuming information through mass media, such as watching television, using social media, and so on. Because shows of violence can be present in every program, including in advertising programs.

\section{REFERENCES}

Anisah, N. (2016). Efek Tayangan Pornografi di Internet Pada Perilaku Remaja di Desa Suka Maju Kecamatan Tenggarong Seberang. E-Journal Ilmu Komunikasi Universitas Mulawarman, 4(1), 115-114.

Bandura, A. (1994). Social Cognitive Theory of Mass Communication. In J.Bryant and Zillmann, eds, Media effects: Advances in Theory and Research. Hillsdale N.J: Erlbaum.

Baran, Stanley., Davis, Dennis. (2000). Mass Communication. Canada: Wadsworth Thomson.

Hutagalung, I. (2017). The Utility of Information in Selective Exposure of Pornography among Teenagers in Indonesia. International Journal of Social Relevance \& Concern, 5(5), 1-7.

(2018). The Influence of Belief, Utility of Information, and Group Support on Selective Exposure to Pornography among Teenagers in Jakarta, Indonesia. International Journal of Engineering \& Technology, 7(2.29), 557-563. https://doi.org/10.14419/ijet.v7i2.29.13817

Kholisoh, N. (2018). Media Literacy Training for Senior High School Students in Administrative Village of Rawa Buaya in Addressing Pornographic Content on You tube Social Media. Proceeding of International Conference on Community Development, 1(1), 200 205. https://doi.org/10.33068/iccd.vol1.iss1.31

Mahsiani, L. (2018). Is Parental Communication or Internet use that makes Pornography in Teenagers? Journal Child Development Studies, 3(1), 59-69.

Mariyati, \& Aini, K. (2018). Studi Kasus: Dampak Tayangan Pornografi Terhadap Perubahan Psikososial Remaja. Jurnal Ilmu Dan Teknologi Kesehatan, 9(2), 64-71.

Matar Boumosleh J, Jaalouk D. (2017). Depression, Anxiety, and Smartphone Addiction in University Students: A Cross Sectional Study. PLoS ONE 12(8): e0182239. https://doi.org/10.1371/ journal. pone.0182239

Satriyandari, Yekti dan Octaviani, Mur. (2017). Hubungan Penggunaan Jenis Media Massa Dengan Kejadian Dating Violence. Journal of Health Studies, 1(1), 78-94.

Santrock, John.W. (2008). Educational Psychology. International ed, New York: McGraw Hill.

Siregar, Nadia Itona. (2014). Pengaruh Video Game Berunsur Kekerasan Terhadap Perilaku Agresif Remaja. Makalah Kolokium, 2(4).

Tankard, James W Jr. dan Werner J Severin. (2008). Teori Komunikasi. Jakarta: Prenada Media Group. 